IP Periodica Polytechnica

Social and Management Sciences

23(1), pp. 60-67, 2015

DOI: $10.3311 /$ PPso. 7810

Creative Commons Attribution (i)

RESEARCH ARTICLE

\section{Financial Key Performance Indicators in Engineering Companies}

\author{
František Milichovský ${ }^{1}$ *
}

Received 29 August 2014; accepted 05 March 2015

\begin{abstract}
Performance is usually defined as system of monitoring individual corporate processes on way to produce the appropriate changes in organizational culture, systems and processes. These activities help to achieve optimal performance agreement targets, allocation of resources, information management on possible modifications of business strategyorsharingtheresultscontinuedindividual goals. Due the performance monitoring the companies can find the Key Performance Indicators, also known as KPIs that help to all organizations define and measure progress toward corporate goals. The objective of this paper is to find trend of improvement by measuring effectiveness of marketing activities. For this reason there was used questionnaire survey, focused on engineering companies operating in Czech Republic. Results and discussion of the paper are based on the analysis of secondary sources and selected data of questionnaire survey, which are involved on measuring the performance of Czech companies. To process the results of the questionnaire survey, there were used both basic types of descriptive statistics and factor analyze on the selected dataset. The data were processed by using the statistical program IBM SPSS Statistics 22. The conclusions provide characteristics of the limitations of research and its potential further direction.
\end{abstract}

\section{Keywords}

indicators, marketing effectiveness, marketing performance

${ }^{1}$ Faculty of Business and Management

Department of Management

Brno University of Technology, Czech Republic

${ }^{*}$ Corresponding author, e-mail: milichovsky@fbm.vutbr.cz

\section{Introduction}

Nowadays, business environment has become highly competitive because of the globalisation. Companies have to improve own decision making process, which must correspond with the world's changes. The long-time business strategy cannot use traditional techniques to corporate improvement. It is necessary to come up with new ideas to be different from competitors in order to survive in global market.

From point of view of performance measurement, there is specific area of corporate performance in SMEs, which conduces to large amount of the interest in economic field to sustainable development. That is important area on which not only Czech companies must focus on. They try to connect different performance systems like social, economic and environmental with corporate performance system. These three dimensions impact whole measurement system of performance and effectiveness (Kocmanová et al., 2011; Coombes and Nicholson, 2013; Pollard and Šimberová, 2012). That is due to different both corporate environment and relationship with stakeholders. For every company there exist various conditions and stakeholder's requirements, which are not similar as well (Kaňovská and Tomášková, 2012).

Historical perspective on performance measurement and management shows the evolution from traditional approaches based on the measurement of financial standards - profit, profitability, cash flow approaches to modern measurement value for the owners and shareholders (Aschenbrennerová, 2010; Hornungová, 2014).

Companies usually use inappropriate or poorly classified indicators what should be crucial for them. Next mistake should be comparison own results of previous periods, where were different conditions for their achievement. Regardless to the obtained results companies have to monitor own processes and activities, in which should be implemented individual components of marketing activities.

\section{Theoretical background}

Engineering companies have become one of the most important parts in Czech industry environment. They measure effectiveness mainly in production process. These companies do 
not measure effectiveness of other corporate parts as in areas of stakeholders, marketing activities, human resources (Zahay and Griffin, 2010).

Industrial area is quite specific. All definitions are focused on other companies in the field and good relationships with them. Industrial marketing should be similar to consumer marketing in odd ways. There are fundamental divergences in individual motives in purchasing process. This means that the goods and services, located at this area, is not for primary consumer (Alvarez and Galera, 2001).

If any company declare that is efficient and effective, then this company could be able to show, which indicators, standards and procedures are used in measurement process. Companies do not lose chance to compare itself with direct competitors in the industry field, as shown by current knowledge, which can be suitably selected according to using tools, whether financial or non-financial (Kotler and Keller, 2006).

Marketing activities are the sub-elements in the marketing process. The marketing process includes, according to Kotler et al. (2007) four parts:

- analysis of marketing opportunities,

- selection of target markets,

- creation of the marketing mix,

- management of marketing efforts.

These four areas contain the necessary marketing role and activities that affect the final marketing strategy. Own definition of marketing activities could be conceptualized from different perspectives. Main perspectives are:

- time perspective,

- market perspective,

- product life-cycle perspective,

- marketing mix perspective.

Siu (2002) and McNamara (1972) described marketing activities as a set of areas in which is necessary to focus on by the enterprises. These activities were adapted into similar perspectives mentioned above by Mohamad, Ramayah and Puspowarsito (2011). In the consumer market (B2C), this file can be divided into nineteen individual marketing activities:

(1) market research, (2) quality control, (3) pricing, (4) credit expansion, (5) relationships with dealers, (6) relationships with customers, (7) public relations, (8) advertising, (9) the business of recruiting, (10) business training, (11) storage, (12) distribution or sale, (13) control of sales, (14) packaging, (15) estimate sales (16) product plan, (17) production plan, (18) inventory management, (19) services associated with the products.

Similar activities are applied in industrial market (B2B) in partial modification according to specific industry.

Marketing activities summary is defined as the set of major activities that must be implemented by the marketing department or its alternative. Despite, the development of information technology describes marketing activities as very relevant, and it helps to the company manage the necessary knowledge and support business processes (Webb et al., 2011).

Comparison of marketing activities list with Total Quality Management concept (next TQM) helps to understand all corporate activities. TQM's goal is management approach partly driven by the customer to achieve full customer satisfaction (Nenadál, 2002). The business activities are covered by the TQM approach in the quality loop, which includes the various phases of the individual marketing activities (Nenadál et al., 2008; Bagad, 2008).

Whole process of marketing strategy definition has been liable to three parts in company: (1) planning and definition, (2) implementation an execution, and (3) control and evaluation. By application these three steps on defined marketing activities there is possible to observe accurate effectiveness (Dudzevičiūtè and Peleckienè, 2010).

Marketing activities, which enter into all corporate activities, have direct influences on business outcomes, especially on financial results. That is mainly due the efficiency of activities and customer satisfaction, which have impact on sales (Ambler, 2000).

Corporate performance has been under lied to continuous measurement and it is depended on requirements of corporate stakeholders (Currie et al., 2009). They usually want maximization of own profit (Shao, 2009; Hornungová and Milichovský, 2013). This maximization is turned on with actual situation in company to reach suggested goals and total market conditions, company operated in.

Indicators which are dedicated for measuring own performance and of course effectiveness should be divided in many ways. From one point of view on indicators is possible to find six groups of indicators. These groups in own essence includes all of corporate marketing activities. They are (Llonch et al., 2002; Ambler and Xiucun, 2003):

1. Financial measures (profits, turnover),

2. Measures of competitive market (market share, promotional share),

3. Measures of consumer behaviour (customer loyalty),

4. Measures of customer intermediate (satisfaction, brand recognition),

5. Measures of direct customer (quality of service, profitability of intermediaries),

6. Measures of innovativeness (revenue from new product launched).

Definition of indicators is hardly depended on individual author view. Sampaio et al (2011) describes indicators as different marketing variables which are generated from marketing efforts. Kerzner (2011) explains indicators as direct way of measuring to get exact figures, which represents individual parts of business in connection with several dimensions. 
In general, indicators could be divided into two main groups - non-financial indicators and financial indicators. Non-financial indicators used other units than financial (e.g. percentage, amount). Financial indicators should be defined as kind of indicators where is possible to formulate exact amount of money they are based on account documents (Ambler and Xiucun, 2003; Ambler, 2002).

Marketing effectiveness is focused on these fields, where is possible to support corporate aims, increase shareholders' values, net cash-flow or increasing net profit (Ambler, 2000; Li, 2011). This effectiveness is created by several levels, which includes five attributes of marketing orientation approach (Kotler and Keller, 2006):

1. customer philosophy,

2. integrated purchase organization,

3. accurate marketing information,

4. strategic orientation,

5. operational efficiency.

It is obvious that marketing indicators are usually used to evaluate the performance achieved in the past to improve future marketing strategies. That is reason why companies have to decide about right combination of appropriate indicators, if they use financial or non-financial (Barwise and Farley, 2004; Ambler et al., 2004). Almost all managers accept more financial indicators than non-financial, but there are possible to find various kinds of indicators. Therefore, there could be problem in defining the ideal set of indicators (Llonch et al., 2002; Chenhall and Langfield-Smith, 2007).

Marketing indicators are designed to find and evaluate efficiency of marketing activities in corporate environment. From point of results view, marketing indicators could be divided into two groups supported by process: (1) internal market indicators, (2) external market indicators. External indicators are focused on measuring of complex brand changes in shorttime period. Internal indicators evaluate innovation levels and responsibilities of employees in company. Processes verify how the individual indicators are obtained and proved (Ambler, 2000; Učeň, 2008; Gaiardelli et al., 2007).

Measurement performance of marketing activities becomes corporate process, which provides performance feedback on gained marketing results. Corporate performance is becoming important part of budgeting in company with direct impact on performance compensations and marketing communication (Clark et al., 2006; Ginevičius et al., 2013).

The usual approach of the management in industrial companies is based on the determination of marketing budget as a percentage of turnovers. However, this approach was supported by the results of the previous period. A more appropriate approach for defining the amount of the marketing budget is the distribution into individual marketing section. That also encourages the increasing requirements for efficient measurements of activities (Christian, 1964).
Effectiveness of marketing activities becomes depended and impacted by group of factors, which create requirements on marketer about implementation of marketing plans (Tuan, 2012; Nwokah and Ahiauzu, 2008).

\section{Methodology}

The objective of this paper is to find trend of improvement by measuring effectiveness of marketing activities. For this reason there was used questionnaire survey, focused on engineering companies in the Czech Republic.

The first part of the paper presents main secondary information, which was processed by scientific articles and other literature. The main part of the paper presents results that were obtained from the primary research - questionnaire survey. Whole primary research was focused on the performance evaluation of enterprises in the Czech Republic in the area of marketing. Questionnaire itself has been designed on:

- theoretical knowledge,

- results of internal project at Brno University of Technology (nr. FP-S-10-21),

- defined indicators by Baroudi (2010).

The obtained results may contribute to the setup of key performance indicators (KPI) for the engineering companies in the Czech Republic in the year 2013.

The respondents in the questionnaire survey were mainly owners and managers of engineering companies in the Czech Republic in 2013. The selection criteria included as follow:

1. geographical location (Czech Republic),

2. classification of economic activities according to $\mathrm{CZ}$ NACE, limited to engineering area.

- 28 - Manufacture of machinery and equipment,

- 29 - Manufacture of motor vehicles, trailers and semitrailers,

- 30 - Manufacture of other transport equipment.

According the chosen CZ-NACE groups, there was defined basic population which consist 7239 engineering companies in Czech Republic. Sample was created by 366 companies that were chosen in random way from company data set. There were returned questionnaires from 147 respondents. Own research survey has been executed during 2013. From point of view of factor analysis this sample is adequate.

There were put research questions, which indicators for measuring effectiveness of marketing activities are used in company as primary indicators.

Results and discussion of the paper are based on the analysis of secondary sources and selected data of questionnaire survey, which are involved on measuring the performance of Czech companies.

Processing the results of the questionnaire survey made use of both the descriptive statistics and factor analysis. These 
methods were applied on the selected data set related to measuring the performance of Czech companies. The data was processed using the statistical software IBM SPSS Statistics 22. The conclusions provide the characteristics of the limitations of the research and its potential further direction.

The factor analysis is based on the selection of correlation and partial correlation coefficients. The correlation coefficient represents the closeness of linear dependence of individual variables and partial correlation coefficients. The partial correlation coefficient shows a similarity of two variables in such a situation that the other variables are assumed constant. If it is possible to explain the dependence of variables using common factors, the partial correlation coefficients are very small, close to zero (Tarnanidis et al., 2015; Conti et al., 2014).

To perform the factor analysis it is necessary to have " $n$ " observations of each $\mathrm{k}$ variables $\left(\mathrm{X}_{1}, \mathrm{X}_{2}, \mathrm{X}_{3}, \ldots \mathrm{X}_{\mathrm{k}}\right)$. The correlation coefficients would be high in absolute terms, if there are linear dependences between the defined variables. On the assumption that condition of dependence of common variables is met, partial correlation coefficients of variables $\left(\mathrm{X}_{1}, \mathrm{X}_{2}, \mathrm{X}_{3}\right.$, $\ldots X_{k}$ ) will be very small.

To assess the suitability of the factor analysis, two tests can be used:

- Kaiser-Meier-Olkin (KMO) is a coefficient which could reach values between 0 and 1 . Its value consists of the rate of squares sum of the correlation coefficients and squares sum of the correlation and partial coefficients.

- The use of Bartlet's sphericity test lies in testing the null hypothesis that the correlation matrix of variables is unit (on diagonal, there are only ones, others are zeros). If the null hypothesis is rejected, the factor analysis may be used for the defined variables.

The factor analysis has shown a relation between the standardized variables $\mathrm{Xi}$ and a linear combination of a lower number of hypothetic factors $\mathrm{Fj}$

$$
X_{i}=a_{i 1} F_{1}+a_{i 2} F_{2}+a_{i 3} F_{3}+\cdots+a_{i 1} F_{m}+e_{i}
$$

for $\mathrm{i}=1,2,3, \ldots \mathrm{k}$, where

$\mathrm{k}$ - number of variables

$\mathrm{m}$ - number of factors; $\mathrm{m}<\mathrm{n}$

$\mathrm{e}_{\mathrm{i}}$ - specific part of variable $\mathrm{Xi}$

For the purposes of verifying the factor analysis, Cronbach's alpha indicator must be used. This indicator is seen as a reliability coefficient, which is used as kind of analogue of the correlation coefficient. Usually, it is possible to reach values in the interval $\langle 0,1\rangle$. Zero as extreme value describes the situation in which individual variables are uncorrelated. On the other hand, the value of 1 describes the correlated variables. When the value is closer to 1 , there is a reported higher degree of conformity (Hrach and Mihola, 2006; DeVellis, 2003).

\section{Results}

Based on the statistical characteristics of the examined group, it could be presented conclusions as an approximate result, limited by the resulting reliability. In the results of the paper there are characteristics of research barriers and future research possibilities.

All financial indicators in Table 1 were chosen according to the results of internal project (Methods of measurement the effectiveness of marketing activities and their applications, nr. FP-S-10-21), realised in Brno University of Technology. Questionnaire included possibility to answer other indicators, but nobody answered.

Table 1 Basic descriptive statistics

\begin{tabular}{|c|c|c|c|}
\hline & Mean & $\begin{array}{c}\text { Std. } \\
\text { deviation }\end{array}$ & Variance \\
\hline Profit per customer & ,79 & ,409 & , 168 \\
\hline Marketing costs & ,13 & ,337 & ,113 \\
\hline Fixed and variable costs &, 82 & ,389 &, 151 \\
\hline Average cost of customer retention & ,26 & ,439 & ,193 \\
\hline Cost per thousands (CPT) &, 04 & ,199 &, 039 \\
\hline Cost per click (CPC) &, 03 &, 163 &, 027 \\
\hline Cost per order (CPO) &, 59 & ,494 & 244 \\
\hline Return on sales (ROS) & ,33 & ,473 & ,224 \\
\hline Return on investment (ROI) &, 20 & ,399 &, 159 \\
\hline $\begin{array}{l}\text { Return on marketing investment } \\
\text { (ROMI) }\end{array}$ & ,03 &, 182 & ,033 \\
\hline Economic value added (EVA) &, 51 &, 502 & ,252 \\
\hline $\begin{array}{c}\text { Earnings before interest, taxes, } \\
\text { depreciation, and amortization } \\
\text { (EBITDA) }\end{array}$ &, 15 & ,358 & ,128 \\
\hline Cost per customer &, 57 & ,497 & ,247 \\
\hline
\end{tabular}

Based on the analyses of descriptive statistical characteristics of the sample, conclusions are presented as an explorative result limited by the resultant reliability. From an analysis of the basic descriptive statistics, it is clear that companies mainly use the following financial indicators:

- Fixed and variable costs

- Profit per customer

- Cost per order

- Cost per customer

For purpose of factor analysis there is necessary to reach value of Kaiser-Meier-Olkin test at least 0,5. For indicators, mentioned above in table $1, \mathrm{KMO}$ is 0,503 which has become in the lowest level of acceptance. Therefore, there were removed indicators, which had the lowest values in anti-image matrix 
- (1) fixed and variable costs, (2) Cost per thousands (CPT). After removing KMO test reached value 0,547.

Factor analysis reveals the reduction of surveyed corporate performance indicators which companies use in their own measurement processes. The main input into factor analysis was a correlation matrix which shows the individual correlation values of the chosen indicators (see Table 2).

Based on the values listed in Table 2, it is possible to say that correlations exist only in the five highlighted relations. These relations are:

- Cost per customer and Cost per orders $(0,470)$,

- Cost per orders and Average cost of customer retention $(0,340)$,

- Economic Value Added and Cost per orders (0,280),

- Cost per customer and Profit per customer (0,260),

- Return on Investment and Average cost of customer retention $(0,254)$.

The total variance of the performance indicators is explained by means of eigenvalues, which represent the total variance explained by each factor. The eigenvalues show that only two items reached the minimum value of 1 .

From this point of view, Extraction Sums of Squared Loadings with cumulative percentage is important. Factor analysis extracted only two factors, which explains almost $60 \%$ of the variance (the exact amount was $59.35 \%$ ). This result confirms the good factor result of the interpreted variance.
The total variance of the compensation trade tools are explained due to eigenvalues, which represents the total variance explained by each factor. In extraction, all components were divided into two new strongest component groups. These new component groups have diverse depth with the previous four components (see Table 2). The eigenvalues were determined by our own figures and only two components have figures over or very close to 1 . That means only two components make up almost $60 \%$ of the total variance of all four components, and have variability as original factors.

\section{Discussion}

In order to assess whether it is possible to use the factor analysis, Kaiser-Meyer-Olkin method (KMO) and Bartlett's test of sphericity were used. The KMO method is based on selective correlation and partial correlation coefficients.

The KMO value range is between 0 and 1 . Each variable correlates perfectly to itself (approximate to 1), but has no correlation to the other variables (approximate to 0 ). In our case, the KMO reached value of 0.6 , which means that the performed level of usefulness of the factor analysis has an average value.

Bartlett's test of sphericity is a statistic test used to examine the hypothesis that the variables are correlated or uncorrelated. According to the KMO, no correlation was found with other variables $(\mathrm{Sig}=0)$. Nevertheless, Bartlett's test of sphericity is significant because of the value, which is lower than 0.05 .

Table 2 Correlation matrix

\begin{tabular}{|c|c|c|c|c|c|c|c|c|c|c|c|}
\hline & 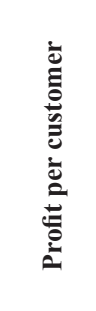 & 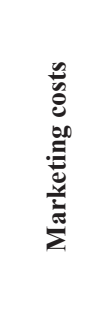 & 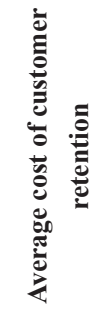 & $\stackrel{U}{0}$ & 巳 & $\stackrel{\mathscr{2}}{\varrho}$ & $\underset{\varrho}{\varrho}$ & $\underset{\approx}{\equiv}$ & $\underset{4}{\mathbb{1}}$ & 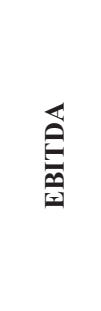 & 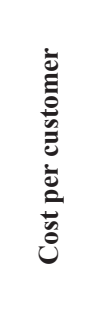 \\
\hline Profit per customer & 1 &, 050 &, 001 & ,086 &,- 029 &, 047 & ,089 & ,097 &, 161 &,- 110 & ,260 \\
\hline Marketing costs &, 050 & 1 &,- 042 &, 185 &,- 293 & ,029 &, $064^{*}$ &, 040 &,- 150 & ,009 &,$- 117 *$ \\
\hline Average cost of customer retention &, 001 &,- 042 & 1 &,- 099 &, 340 &,- 088 &,- 254 &, 061 & ,081 &,- 161 & ,197 \\
\hline $\mathrm{CPC}$ & ,086 &, $185^{*}$ &,- 099 & 1 &,$- 029 *$ &,- 118 &,- 083 &,- 031 &,$- 171^{*}$ &,- 070 &, 145 \\
\hline $\mathrm{CPO}$ &,- 029 &,$- 293 * *$ &, $340 * *$ &,- 029 & $1 * *$ &,$- 078 * *$ &,- 207 &, 158 &, $280 * *$ &, $044 * *$ &, 470 \\
\hline ROS & ,047 & ,029 &,- 088 &,- 118 &,- 078 & 1 &, 556 &, 106 & ,318 &, 108 &,- 087 \\
\hline ROI & ,089 &, 064 &,$- 254 * *$ &,- 083 &,- 207 &, $556^{* *}$ & 1 &, 190 & ,110 &, $175^{* *}$ &,- 089 \\
\hline ROMI & ,097 &, 040 & ,061 &,- 031 & ,158 &, 106 & ,190 & 1 &, 034 & ,237 &, 163 \\
\hline EVA &, 161 &,- 150 &, 081 &,- 171 & ,280 & ,318 &, $110^{*}$ &, 034 & 1 & ,220 &, $086^{*}$ \\
\hline EBITDA &,- 110 & ,009 &,- 161 &,- 070 &, 044 & ,108 &, 175 &, 237 &, 220 & 1 &,- 176 \\
\hline Cost per customer &, $260 * *$ &,- 117 &, $197 *$ &, $145^{* *}$ &, 470 &,$- 087^{*}$ &,- 089 &, $163 * *$ & ,086 &,$- 176^{*}$ & 1 \\
\hline
\end{tabular}

*. Correlation is significant at the 0.05 level (2-tailed).

**. Correlation is significant at the 0.01 level (2-tailed). 
Table 3 Rotated component matrix

\begin{tabular}{|c|c|c|c|c|}
\hline & Return & Customer results & Creation of value & Profitability \\
\hline Profit per customer & 0.329 & 0.676 & -0.137 & -0.180 \\
\hline Marketing costs & 0.090 & -0.008 & -0.647 & 0.085 \\
\hline $\begin{array}{c}\text { Average cost of customer } \\
\text { retention }\end{array}$ & -0.358 & 0.292 & 0.381 & 0.002 \\
\hline $\mathrm{CPC}$ & -0.180 & 0.321 & -0.590 & 0.058 \\
\hline $\mathrm{CPO}$ & -0.341 & 0.429 & 0.557 & 0.347 \\
\hline ROS & 0.797 & 0.009 & 0.170 & 0.069 \\
\hline ROI & 0.798 & -0.033 & -0.096 & 0.172 \\
\hline ROMI & 0.096 & 0.244 & -0.098 & 0.742 \\
\hline EVA & 0.391 & 0.184 & 0.579 & 0.160 \\
\hline EBITDA & 0.170 & -0.320 & 0.076 & 0.746 \\
\hline Cost per customer & -0.184 & 0.789 & 0.124 & 0.116 \\
\hline Cronbach's alpha & 0.707 & 0.414 & 0.430 & 0.333 \\
\hline
\end{tabular}

Extraction Method: Principal Component Analysis.

Rotation Method: Varimax with Kaiser Normalization. Rotation converged in 17 iterations

For the correctness of the factor analysis and accepting the results, it is important to obtain a Cronbach's alpha value of over 0.7 . Otherwise, either the sample or the questionnaire requires improving. Cronbach's alpha is a measure of internal consistency that is closely related to a set of items as a group. A "high" value of alpha is often used (along with substantive arguments and possibly other statistical measures) as evidence that the items measure an underlying (or latent) construct.

However, a high Cronbach's alpha does not imply that the measure is unidimensional. If, in addition to measuring internal consistency, you wish to provide evidence that the scale in question is unidimensional, additional analyses may be performed. The exploratory factor analysis is one of the methods for checking dimensionality. Cronbach's alpha is not a statistical test; it is a coefficient of reliability (or consistency).

It could be written as a function of the number of test items and the average inter-correlation among the items. Below, for conceptual purposes, we show the formula for the standardized Cronbach's alpha:

$$
\alpha=(N \times \bar{c}) /[\mathrm{v}+(\mathrm{N}-1) \times \bar{c}]
$$

where:

$\mathrm{N}$ is equal to the number of items,

c-bar is the average inter-item covariance among the items,

$\mathrm{v}$-bar equals the average variance.

If the values were to increase the number of items $(\mathrm{N})$, it is possible to increase Cronbach's alpha. Moreover, if the average inter-item correlation is low, the alpha will be low. As the average inter-item correlation increases, Cronbach's alpha increases as well. The values of Cronbach's alpha could be from 0 to 1 . If the values were close to 0.5 , it signifies a bad level of internal consistency. Over 0.7 means that the value is acceptable and values close to 1 are excellent (Hinton et al., 2004).

According to observed results, value of Cronbach's alpha was only for Return factor. From other factors there is Creation value near the minimum of Cronbach's alpha. Unfortunately, value of this index is only 0,430 . Therefore, there was used only Return factor such significant factor.

Calculation final value of acceptable factor needs the transformation of individual coefficients. These coefficients have become the significance of used elements. Their total sum has to be equal 1 . The index of return factor was defined by this procedure:

$$
\text { index of return factor }=0,464 \times R O I+0,536 \times R O S
$$

where

$\boldsymbol{R O I}$ is Return on investment

$\boldsymbol{R O S}$ is Return on sales

On the basis of the calculation index of the Return factor, the mean value of the index was found. This value represents the average value for each company in data set. This value reflects low bonds within factor (see Table 4). This is due to the range of possible answers listed in the questionnaire.

To modify the index, it is necessary to use a rating scale for companies, which determines whether the tool is used. For the calculation of the total index, it is necessary to put the answers of individual respondents into the appropriate index formula.

Table 4 Basic statistics of return factor

\begin{tabular}{cccc}
\hline & Mean & Std. Deviation & Variance \\
\hline Index of return factor &, 2702 & 0,38839 & 0,151 \\
\hline
\end{tabular}


It is obvious that evaluation of financial indicators needs exact values. Unfortunately, primary research was focused on ways of measurement marketing effectiveness. Therefore, exact values of individual financial indicators could not be assess.

\section{Conclusion}

The main goal of presented research was to define set of the KPIs in Czech engineering companies. The correct choice of performance indicators is important part of the corporate strategic process, because well-defined KPIs can help to the companies realise plans and controls due their priorities.

Limitation of this paper is focusing only on domestic companies. Therefore it is necessary to do next researches where is possible to use knowledge not only in domestic business environment, but especially in international environment to ascertain the influence of corporate performance measurement system.

The paper is focused on the area of marketing performance in relation to KPIs. Currently more and more companies use in their management performance measurement that is important not only for the actual management, but also for other interested parties involved in the entity with each other stakeholders. Performance measurement is an important tool for sustainable management. And sustainability is a term that can be more and more often heard from various areas of the Czech environment.

Empirical research deals with factor analysis that gives up reduction of surveyed corporate performance indicators which companies use in own measurement process. Main input into factor analysis was correlation matrix. Results of the factor analysis are four component groups. All of these groups had to be evaluated by Cronbach's alpha (with value over 0,5). Therefore, it was accepted only one component group - Return factor.

Monitoring and constantly evaluating and improving the results of these indicators, should lead to the growth of economic success that is key goal within the chosen strategy for many of them.

\section{References}

Aschenbrennerová, H. (2010) Měřením a řízením výkonnosti ke zvyšování konkurence schopnosti malých a středních průmyslových podniků v období globální finanční krize. (Measurement and performance management to increase the competitiveness of small and medium-sized in industrial companies during the global financial crisis.) Úspěch produktivita a inovace v souvislostech. 5 (1). (In Czech)

Alvarez, P., Galera, C. (2001) Industrial marketing applications of quantum measurement techniques. Industrial Marketing Management. 30 (1). pp. 13-22. DOI: 10.1016/s0019-8501(99)00064-4

Ambler, T. (2000) Marketing metrics. Business Strategy Review. 11 (2). pp. 59-66.

Ambler, T. (2002) Market metrics: What should we tell the shareholders? The Journal of Risk Finance. 10 (1). pp. 47-50. DOI: $10.1108 / 09657960210697418$

Ambler, T., Kokkinaki, F., Puntoni, S. (2004) Assessing marketing performance: Reasons for metrics selection. Journal of Marketing Management. 20. pp. 475-498. DOI: 10.1362/026725704323080506
Ambler, T., Xiucun, W. (2003) Measures of marketing success: A Comparison between China and the United Kingdom. Asia Pacific Journal of Management. 20 (2). pp. 267-281. DOI: 10.1023/A:1023896601290

Bagad, V. S. (2008) Total quality management. In: Peth, S.: Technical Publications Pure.

Baroudi, R. (2010) KPI mega library.

Barwise, P., Farley, J. U. (2004) Marketing metrics: Status of six metrics in five countries. European Management Journal. 22 (3). pp. 257-262. DOI: 10.1016/j.emj.2004.04.012

Chenhall, R. H., Langfield-Smith, K. (2007) Multiple perspectives of performance measures. European Management Journal. 25 (4). pp. 266-282. DOI: 10.1016/j.emj.2007.06.001

Christian, R. C. (1964) A „Systems approach” to industrial marketing communications. Journal of Marketing. 28 (4). pp. 64-67. DOI: $10.2307 / 1249573$

Clark, B. H., Abela, A. V., Ambler, T. (2006) An Information processing model of marketing performance measurement. Journal of Marketing Theory and Practice. 14 (3). pp. 191-208. DOI: 10.2753/MTP1069-6679140302.

Conti, G., Frühwirth-Schnatter, S., Heckmanc, J. J., Piateke, R. (2014) Bayesian exploratory factor analysis. Journal of Econometrics. 183 (1). p. 31-57. DOI: 10.1016/j.jeconom.2014.06.008

Coombes, P. H., Nicholson, J. D. (2013) Business model and their relationship with marketing: a systematic literature review. Industrial Marketing Management. 42 (5). pp. 656-664. DOI: 10.1016/j.indmarman.2013.05.005

Currie, R., Seaton, S., Wesley, F. (2009) Determining stakeholders for feasibility analysis. Annals of Tourism Research. 36 (1). pp. 41-63. DOI: 10.1016/j.annals.2008.10.002

DeVellis, R. F. (2003) Scale Development: Theory and Application. London: Sage Publications.

Dudzevičiūtè, G., Peleckienė, V. (2010) Marketing strategy process: Quantitative analysis of the customers' satisfaction. Business: Theory and Business. 11 (4). pp. 345-352. DOI: 10.3846/btp.2010.37

Gaiardelli, P., Saccani, N. Songini, L. (2007) Performance Measurement of the After-sales Service Network - Evidence from the Automotive Industry. Computers in Industry. 58 (7). pp. 698-708. DOI: 10.1016/j.compind.2007.05.008

Ginevičius, R., Podvezko, V., Ginevičius, A. (2013) Quantitative evaluation of enterprise marketing activities. Journal of Business Economics and Management. 14 (1). pp. 200-212. DOI: 10.3846/16111699.2012.731143.

Hinton, P. R., Brownlow, Ch., McMurray, I., Cozens, B. (2004) SPSS explained. Hove: Routledge.

Hornungová, J., Milichovský, F. (2013) Profit indicators in performance systems in the Czech companies. Acta Universitatis Agriculturae et Silviculturae Mendelianae Brunensis. 61 (2). pp. 345-352.

DOI: 10.11118/actaun201361020345

Hornungová, J. (2014) Development of Concepts and Models of Performance Evaluation from the 19th Century to the Present. DANUBE: Law and Economics Review. 5 (2). pp. 143-154. DOI: 10.2478/danb-2014-0008

Hrach, K., Mihola, J. (2006) Metodické př́stupy ke konstrukci souhrnných ukazatelů. (Methodological approaches to aggregate indicators construction.) Statistika. 86 (5). pp. 398-418. (In Czech)

Kaňovská, L. Tomášková, E. (2012) Interfunctional Coordination at Hi-Tech Firms. Engineering Economics. 23 (1). pp. 70-76. DOI: $10.5755 /$ j01.ee.23.1.1224

Kerzner, H. (2011) Project management metrics, KPIs, and dashboards: A Guide to measuring and monitoring project performance. New Jersey: John Wiley \& Sons. 
Kocmanová, A., Dočekalová, M., Němeček, P. Šimberová, I. (2011) Sustainability: Environmental, Social and Corporate Governance Performance in Czech SMEs. Proceedings of the 15th World Multi-Conference on Systemics, Cybernetics and Informatics (WMSCI). IFSR, Orlando, USA. pp. 94-99.

Kotler, P., Wong, V., Saunders, J., Armstrong, G. (2007) Moderní marketing. (Modern marketing.) Praha: Grada Publishing. (In Czech)

Kotler, P., Keller, K. L. (2006) Marketing Management. New Jersey: Pearson Education.

Li, L.-Y. (2011) Marketing metrics usage: Its predictor and implications for customer relationship management. Industrial Marketing Management. 40 (1). pp. 139-148. DOI: 10.1016/j.indmarman.2010.09.002

Llonch, J., Eusebio, R., Ambler, T. (2002) Measures of marketing success: A Comparison between Spain and the UK. European Management Journal. 20 (4). pp. 414-422. DOI: 10.1016/S0263-2373(02)00064-6

McNamara, C. P. (1972) The present status of the marketing concept. Journal of Marketing. 36 (1). pp. 50-57. DOI: 10.2307/1250868

Mohamad, O., Ramayah, T., Puspowarsito, H. (2011) Incidence of marketing activities in medium-sized manufacturing firms in Indonesia: Comparing export intenders and non-export intenders. International Journal of Business and Society. 12 (1). pp. 89-102.

Nenadál, J., Noskievičová, D., Petříková, R., Plura, J., Tošenovský, J. (2008) Moderní management jakosti: Principy, postupy, metody. (Modern quality management: Principles, procedures, methods.) Praha: Management Press. (In Czech)

Nenadál, J. (2002). Moderni systémy řizeni jakosti: Quality management. (Modern quality management system: Quality management.) Praha: Management Press. (In Czech)

Nwokah, N. G., Ahiauzu, A. I. (2008) Managerial competencies and marketing effectiveness in corporate organizations in Nigeria. Journal of Management Development. 27 (8). pp. 858-878.

DOI: $10.1108 / 02621710810895677$
Pollard, D., Šimberová, I. (2012) Marketing in high technology firms. Proceedings of the 7th International Scientific Conference Business and Management. pp. 465-471. DOI: 10.3846/bm.2012.061

Sampaio, C. H., Simões, C., Perin, M. G., Almeida, A. (2011) Marketing metrics: Insights from Brazilian managers. Industrial Marketing Management. 40 (1). pp. 8-16. DOI: 10.1016/j.indmarman.2010.09.005.

Shao, G. (2009) Toward a stakeholder model of corporate governance: Evidence from U.S. media companies. The University of Alabama: College of Communication and Information Sciences.

Siu, W. (2002) Marketing activities and performance: A comparison of the Internet-based and traditional small firms in Taiwan. Industrial Marketing Management. 31 (2). pp. 177-188.

Tarnanidis, T., Owusu-Frimpong, N., Nwankwo, S., Omar, M. (2015) A confirmatory factor analysis of consumer styles inventory: Evidence from Greece. Journal of Retailing and Consumer Services. 22. pp. 164-177. DOI: 10.1016/j.jretconser.2014.07.001

Tuan, L. T. (2012) Marketing effectiveness and its precursors. Asia Pacific Journal of Marketing and Logistics. 24 (1). pp. 125-152. DOI: $10.1108 / 13555851211192731$

Učeň, P. (2008) Zvyšováni výkonnosti firmy na bázi potenciálního zlepšení. (Increasing corporate performance based on potential improvements.) Praha: Grada Publishing. (In Czech)

Webb, J. W., Ireland, D. R., Hitt, M. A., Kistruck, G. M., Tihanyi, L. (2011) Where is the opportunity without the customer? An integration of marketing activities, the entrepreneurship proces, and institutional theory. Journal of the Academy of Marketing Science. 39 (4). pp. 537-554. DOI: 10.1007/s11747-010-0237-y

Zahay, D., Griffin, A. (2010) Marketing strategy selection, marketing metrics, and firm performance. Journal of Business \& Industrial Marketing. 25 (2). pp. 84-93. DOI: 10.1108/08858621011017714 